\title{
Religious Based Responsive Counseling to Improve Students Life Skill
}

\author{
Hera Heru Sri Suryanti, Sri Hartini
}

\begin{abstract}
This research was directed to solve problem on low life skill students, namely : ignorance attitude, dishonest to posent, dishonest in doing assigment from lectuter, and dishonest toward their own attitude. Life skill constitutes personal competent which must be mastered by student to life harmonic in their environtment. Students with low life skill can not be a creative and innovative toward their knowledge, attitude and skills. If this problems were not overcame, so it can hider their assignment goal and surely hider nett development. Guidance and conseling in university has a duty to prepare students to life indepently in society, so one at the conseling is which was appired to increase students life skill. Responsife conseling constitutes did conseling for students who hate need or problem urgent help.

The objectives at this study is increasing low life skill student to high life skill student. The method used to reach the objective is qualitative research ( Guidance and Conseling Action Research ). The subject at research is students teacher training and education faculity, meanwhile interview observation and test were applied to collect data. To get data validity, the reseacher used triangulation, college discussion and memberchecking. More over, interative analysis was used to analysis the data. The results showed that in cycle one and cycle two, religious based responsive conseling improve students life skill.
\end{abstract}

Index Terms: Life Skill, Responsive Conseling, Religious Based.

\section{INTRODUCTION}

The implementation of guidance and counseling consists of guidance activities and counseling activities. Guidance activities are the process of giving assistance to individuals in order to be able to understand themselves and their environment, while counseling activities are the process of providing assistance through counseling interviews by an expert to individuals who are experiencing things leading to the overcoming problems faced by clients. Individuals who have problems in the scope of a college can consist of students, lecturers, and employees. The solution can be done first on students because they as individuals who will be developed into reliable and noble human resources with a high Life Skills.

Students are one of the nation's assets that are expected to build the nation through its achievements. In this case, the students include educated community who should have a mental, strong personality in dealing with problems, both personal and social problems in their life. In fact, from the results of observations on May 2018, especially in FKIP-Educational Faculty of Education Science of UNISRI-Slamet Riyadi University, there are still found low Life Skill students which were not in line with the expectations mentioned. In carrying out their learning assignments it still often causes problems, so they fall into a malladaptive behavior. Students are easily influenced by their environment which does not support the achievement of educational goals

The right implementation of guidance and counseling in Higher Education will be able to assist students in overcoming their problems. So that, the students can develop their Life Skills normally and optimally. Therefore, emotional intelligence-based group counseling is effective to enhance the students' responsibility (Educational E-Journal. Vol-V, Issue-IV, Oct-Nov-Dec 2016). The guidance service model conducted by lecturers gives a significant influence on students' behavior. To overcome the low level of Life Skills, it is necessary to apply a guidance service model that is able to improve student Life Skills through increasing faith, arousing confidence, responsibility, honesty, respect for others, humility, and compassion. The guidance service model to be implemented to improve Life Skills for students is still rare. Hence, it is necessary to implement religious-based Responsive Services in more curative strategy. Strategies used are a Life Skills Counseling and a Consultation that can effectively and efficiently improve student Life Skills. The Skills counseling is also called life skills helping (LSH) or life skills therapy is an integrative model to help clients to be able to develop self helping skills (Syamsu Yusuf, 2012: 57).

The results of the previous study, First: A Student Skills Improvement in Individual Counseling by making Counseling Guidance Laboratory effective in Engineering Courses and Counseling, Second: A Development of Problem Based Learning Models in Improving Student Achievements, Third: The College Discipline Improvement through Group Counseling for Semester III BK FKIP-Educational Faculty of Education Science Of UNISRI-Slamet Riyadi University Program Students. Fourth: The Development of Youth Counseling Model Based on Comprehensive Intelligence to Improve Student Characters. 
Fifth: The Effectiveness of Content Mastery Services in Group Settings to Increase Student Flexibility of BK FKIP-Educational Faculty Of Education Science Of UNISRI-Slamet Riyadi University Study Program. Sixth: The Role of religious-based behavioristic counseling in changing student delinquency. For this reason, it is necessary to follow up with the next research activity

The results of the survey in July 2018 in the scope of the Counseling Guidance Study Program found several students who behaved in a low Life Skill category such as smoking out of place, littering, irresponsiveness to the cleanliness of the learning environment, lack of ethical communication, lack of responsible for their duties, lack of tolerance for friends and do worship not in order manner.

Lecturers as educators have a work target of teaching and educating students well, not only the knowledge transfer work that is being pursued but also overcoming the low students' Life Skill. Increasing students life skills is an important matter. One way that can be done is by implementing guidance services. The guidance service model that is considered appropriate to increase student life skills is a religious-based information service model, because according to the essential nature of human beings it is a religious being (homo religious) that is a creature that has the nature to understand and accept the values of truth originating from religion, and at the same time making religious truth as a reference for attitudes and behavior. This religious-based information service is related to efforts to integrate religious values in the process of guidance and counseling. For this reason, teachers / counselors are required to have an understanding of human nature according to religion and the role of religion in human life (Syamsu Yusuf and Juntika Nurihsan, 2012: 135).

Quality Individu "the skilled person" have Characters :

1) Responsiveness, namely the skills associated with awareness of his existence, understanding his feelings, understanding his internal motivation, and agreement, and sensitivity to anxiety and guilt.

2) Realism, which is the ability to think realistically

3) Relating, namely skills in initiative, listening, giving care, cooperating, asserting and managing anger and conflict

4) Rewarding activity, which includes identifying skills, interest in working skills, study skills (learning), skills utilizing leisure time, and skills in maintaining physical health.

5) Right \& Wrong, which is related to the skill of applying ethics in social life.

Based on this description, it is necessary to conduct a research on Improving Student Life Skill through responsive Religious-Based services.

This study reviews the condition of student Life Skill in implementing religious-based responsive services to improve Life Skill, as well as reviewing the advantages and disadvantages of religious-based responsive services in improving Student Life Skill.

\section{RESEARCH METHOD}

The method used in this study is a descriptive qualitative research followed by PTBK (Selected Area, Collect Data, Organize data, Analyze and interpret data, and Take Action) ( Dede Rahmad hidayat, 2012: 19). The study was conducted at the FKIP-Educational Faculty Of Education Science of Solo Raya. The research is planned for 6 months. It began with data collection about students whose life skills are low then proceeded with the application of religious-based responsive services to these students.

The Population. According to Suharsimi Arikunto (2002: 108), the population is the whole research subject or individuals who have the same characteristics. The population is the generalization region consisting of objects or subjects that have certain qualities and characteristics set by researchers to be studied and then conclusions are drawn (Sugiyono. 2010: 90). The populations in this study were FKIP-Educational Faculty Of Education Science of Solo Raya. The Sample is the part of the number and characteristics of the population. (Sugiyono. 2010: 81). The sample in this study was the student of BK-Counseling Guidance study program. The Sampling is the process of selecting a certain number of populations to be able to represent the population (Nasution, 2002: 86). The sample selection technique in this study is purposive sampling, which is the selection of samples is based on certain considerations. The selection of informants is based on position and access to problems in depth so that it can be used as a solid data source.

The Data Collection Technique. There are several techniques used in collecting data, namely: The Observation is a technique of collecting data that is carried out systematically and deliberately, through observation and recording of the symptoms under investigation (Gantina, 2011: 57). The observation in this study were conducted to collect data of low life skills students. The Interview is a meeting of two or more people with the intention to dig up information in the form of a person's facts or opinions for a particular purpose (Lexy. J. Moleong, 2002: 135). This interview was conducted for students to find out information about their high and low life skills. The Focus Group Discussion (FGD) is a way of group interviews, and the data obtained at once is more robust data because it has been discussed by many speakers as members of the discussion group (HB Sutopo, 2006: 63). The FGD will be conducted between researchers and related subjects, to strengthen the data collected. The Test is a tool or procedure used to find out or measure something in the atmosphere, by means and rules that have been determined (Suharsimi Arikunto, 2002: 52). The test will be given in the form of a test form to determine the improvement of student life skills.

The Data validity, to increase credibility of data using extension of observation, persistence of research, triangulation, peer discussion, negative case analysis, and member checking (Emzir, 2010) 
The Data Analysis Techniques, carried out based on the stages of research, which each stage has its own analysis model. Analysis of the data used in the first stage is an interactive analysis model as stated by Miles and Huberman (1992), which includes stages: 1) data collection, 2) data reduction to dispose of irrelevant data in the process of preparing proto-models , 3) presentation (display) of data, in the form of classification, appearance, description, division and so on, and 4) conclusion or verification.

The indicator of success is when $75 \%$ of the number of Clients / Conselients experience a change in behavior to be good (The Increase Life Skill)

\section{RESEARCH RESULT AND DISCUSSION}

The Research result

\section{A. The condition of students Life Skill of FKIP-Educational Faculty of Education Science of UNISRI-Slamet Riyadi University Students}

FKIP students are prepared as instructors and educators so they need to be equipped with high Life Skill to be able to work in the community well. However, there are still students who have low Life Skills.

The condition of student Life Skills, especially Guidance and Counseling Students as varied research subjects. Life skills that are expected to be formed in the skilled person have the following characters; Responsiveness, namely skills related to awareness of his existence, understanding of his feelings, understanding of his internal motivation, and agreement, and sensitivity to anxiety and guilt; Realism, which is the ability to think realistically; Relating, namely skills in initiating, listening, caring, collaborating, asserting and managing anger and conflict; Rewarding activity, which includes identifying skills, interest in working skills, study skills (learning), skills utilizing leisure time, and physical health care skills; Right $\boldsymbol{\&}$ Wrong, which is related to the skill of applying ethics in social life.

While the life skill conditions of assisted students to improve are as following table 1

Table 1: Student Conditions before Religious-Based Life Skills Counseling Being Committed

\begin{tabular}{llll}
\hline No & Name & $\begin{array}{l}\text { The Characteristics of The } \\
\text { Skilled Person }\end{array}$ & $\begin{array}{l}\text { The } \\
\text { Condition }\end{array}$ \\
\hline 1 & DD & 1. Responsiveness & Fair \\
& 2. Realism, & Fair \\
& 3. Relating, & Fair \\
& 4. Rewarding activity, & Poor \\
& 5. Right \& Wrong, & Poor \\
\hline 2 & IS & 1. Responsiveness, & Fair \\
& 2. Realism,. & Fair \\
& 3. Relating, & Fair \\
& 4. Rewarding activity, & Poor \\
& 5. Right \& Wrong, & Poor \\
\hline 3 & YR & 1. Responsiveness, & Fair \\
& 2. Realism,. & Fair \\
& 3. Relating, & Poor \\
& 4. Rewarding activity, & Poor \\
& 5. Right \& Wrong, & Poor \\
\hline
\end{tabular}

\section{B. The Commission of Religious Based Responsive Services in Increasing Student Life Skills.}

Religious-based responsive services are more curative. The strategies used are life skill counseling and consultation.

\section{1) The First Religious Based Life Skills Counseling Implementation}

Religious-based life skills counseling was conducted in November 2018, at the BK-Counseling Guidance laboratory. The group is formed by its members consisting of five students who deal with: Responsiveness, namely skills related to awareness of their existence, understanding their feelings, understanding their internal motivation, and agreement, and sensitivity to anxiety and guilt. Realism, which is the ability to think realistically; Relating, namely skills in initiative, listening, giving care, cooperating, asserting and managing anger and conflict; Rewarding activity, which includes identifying skills, interest in working skills, study skills (learning), skills utilizing leisure time, and skills in maintaining physical health. Right $\&$ Wrong, which is related to the skill of applying ethics in social life, still needs to be improved.

The process of life skills counseling is through five stages. First are developing relationships, identifying and clarifying problems. Second are assessing the problem and re-identifying the main problem of the client. Third are formulating goals and planning interventions. Fourth is providing interventions to develop client skills to help themselves (Self Helping), in this fourth stage the Counselor includes material in the verses of the Qur'an related to the problems of the Client. Fifth are ending counseling and consolidating.

In the first counseling, it was more focused on the first stage, namely developing relationships, identifying and clarifying problems and the second stage, namely assessing problems and re-identifying the main problems of the client.

The results of observation from the implementation of religious-based life skills counseling showed that 3 clients had experienced an increase in their skills after counseling and consultation. This is seen from their daily habits changed better.

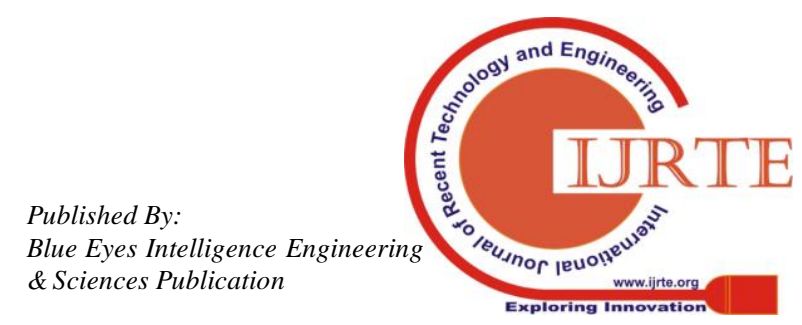


Table 2: The Condition of the Guidance and Counseling Students after First Counseling Commission.

\begin{tabular}{|c|c|c|c|}
\hline No & Name & $\begin{array}{l}\text { The Characteristics the skilled } \\
\text { person }\end{array}$ & $\begin{array}{l}\text { The Condi } \\
\text { tion }\end{array}$ \\
\hline 1 & $\mathrm{DD}$ & $\begin{array}{l}\text { 1. Responsiveness, } \\
\text { 2. Realism, } \\
\text { 3. Relating, } \\
\text { 4. Rewarding activity, } \\
\text { 5. Right \& Wrong, }\end{array}$ & $\begin{array}{l}\text { High } \\
\text { High } \\
\text { Fair } \\
\text { Fair } \\
\text { Poor } \\
\end{array}$ \\
\hline 2 & IS & $\begin{array}{l}\text { 1. Responsiveness, } \\
\text { 2. Realism, } \\
\text { 3. Relating, } \\
\text { 4. Rewarding activity, } \\
\text { 5. Right \& Wrong, }\end{array}$ & $\begin{array}{l}\text { High } \\
\text { Fair } \\
\text { Fair } \\
\text { Fair } \\
\text { Poor }\end{array}$ \\
\hline 3 & YR & $\begin{array}{l}\text { 1. Responsiveness, } \\
\text { 2. Realism, } \\
\text { 3. Relating, } \\
\text { 4. Rewarding activity, } \\
\text { 5. Right \& Wrong, }\end{array}$ & $\begin{array}{l}\text { High } \\
\text { Fair } \\
\text { Fair } \\
\text { Fair } \\
\text { Poor }\end{array}$ \\
\hline 4 & AS & $\begin{array}{l}\text { 1. Responsiveness, } \\
\text { 2. Realism, } \\
\text { 3. Relating, } \\
\text { 4. Rewarding activity, } \\
\text { 5. Right \& Wrong, }\end{array}$ & $\begin{array}{l}\text { Fair } \\
\text { Fair } \\
\text { Poor } \\
\text { Poor } \\
\text { Poor }\end{array}$ \\
\hline 5 & RW & $\begin{array}{l}\text { 1. Responsiveness, } \\
\text { 2. Realism, } \\
\text { 3. Relating, } \\
\text { 4. Rewarding activity, } \\
\text { 5. Right \& Wrong, }\end{array}$ & $\begin{array}{l}\text { Fair } \\
\text { Poor } \\
\text { Poor } \\
\text { Poor } \\
\text { Poor }\end{array}$ \\
\hline
\end{tabular}

After the first counseling, a reflection was carried out to determine the religious-based life skills counseling material that will be applied to the next counseling. During the time of counseling on certain days, 3 (three) clients consulted effectively.

\section{2) The Counseling Commission of the Second Religious Based Life Skills}

Religious-based life skills counseling is conducted in December 2018. Counseling for religious-based life skills is carried out with more emphasis on the use of the verses of the Qur'an because by chance all the clients or counselors are Muslim. In this second counseling, it focuses more on the third stage, namely formulating objectives and planning interventions. The fourth stage is to provide interventions to develop the skills of the client to help himself (Self Helping) and the fifth stage ends counseling and consolidation. The results of observations on the implementation of religious-based life skills counseling showed that all clients / counselees had improved behavior change. This can be achieved because it is assisted by consultations in between the time of counseling of the days apart from the commission of counseling of 5 (five) Clients conducting intensive consultations.
Table 3: The Condition of the Guidance and Counseling Students after The Second Counseling

\begin{tabular}{|c|c|c|c|}
\hline No & Name & $\begin{array}{l}\text { The Characteristics of the } \\
\text { skilled person }\end{array}$ & $\begin{array}{l}\text { The } \\
\text { Condition }\end{array}$ \\
\hline 1 & $\mathrm{DD}$ & $\begin{array}{l}\text { 1. Responsiveness, } \\
\text { 2. Realism, } \\
\text { 3. Relating, } \\
\text { 4. Rewarding activity, } \\
\text { 5. Right \& Wrong. }\end{array}$ & $\begin{array}{l}\text { High } \\
\text { High } \\
\text { High } \\
\text { Fair } \\
\text { Fair }\end{array}$ \\
\hline 2 & IS & $\begin{array}{l}\text { 1. Responsiveness, } \\
\text { 2. Realism, } \\
\text { 3. Relating, } \\
\text { 4. Rewarding activity, } \\
\text { 5. Right \& Wrong. }\end{array}$ & $\begin{array}{l}\text { High } \\
\text { High } \\
\text { Fair } \\
\text { Fair } \\
\text { Fair }\end{array}$ \\
\hline 3 & YR & $\begin{array}{l}\text { 1. Responsiveness, } \\
\text { 2. Realism, } \\
\text { 3. Relating, } \\
\text { 4. Rewarding activity, } \\
\text { 5. Right \& Wrong, }\end{array}$ & $\begin{array}{l}\text { High } \\
\text { High } \\
\text { Fair } \\
\text { Fair } \\
\text { Fair }\end{array}$ \\
\hline 4 & AS & $\begin{array}{l}\text { 1. Responsiveness, } \\
\text { 2. Realism, } \\
\text { 3. Relating, } \\
\text { 4. Rewarding activity, } \\
\text { 5. Right \& Wrong, }\end{array}$ & $\begin{array}{l}\text { High } \\
\text { Fair } \\
\text { Fair } \\
\text { Fair } \\
\text { Fair }\end{array}$ \\
\hline 5 & RW & $\begin{array}{l}\text { 1. Responsiveness, } \\
\text { 2. Realism, } \\
\text { 3. Relating, } \\
\text { 4. Rewarding activity, } \\
\text { 5. Right \& Wrong }\end{array}$ & $\begin{array}{l}\text { Fair } \\
\text { Fair } \\
\text { Fair } \\
\text { Fair } \\
\text { Poor }\end{array}$ \\
\hline
\end{tabular}

Changes in the counselee behavior of the results of religious-based life skills counseling above are relevant to the theory of Syamsu Yusuf and Juntika Nurihsan, 2012: 133. Students have a nature as religious beings. Religious nature is a capital to achieve high life skills. If the environmental conditions are conducive, giving teachings, guidance by giving good motivation and obedience in practicing religious values, students will evolve to noble human beings. The characteristic of the skilled person is achieved. One of the intended environments is the implementation of religious-based life skills counseling.

\section{3) Recapitulation of Results of the Counseling of Religious Based Life Skills.}

Name: DD

\begin{tabular}{llll}
\hline $\begin{array}{l}\text { The } \\
\text { Characteristics } \\
\text { of the skilled } \\
\text { person }\end{array}$ & $\begin{array}{l}\text { Pre } \\
\text { Counseling }\end{array}$ & $\begin{array}{l}\text { Counseling } \\
\text { I }\end{array}$ & $\begin{array}{l}\text { Counseling } \\
\text { II }\end{array}$ \\
\hline $\begin{array}{l}\text { Responsiveness } \\
\text { Realism }\end{array}$ & Fair & High & High \\
$\begin{array}{l}\text { Relating } \\
\text { Rewarding }\end{array}$ & Fair & High & High \\
activity & Poor & Fair & High \\
Right \& Wrong & Poor & Poor & Fair \\
\hline
\end{tabular}


Name: IS

\begin{tabular}{llll}
\hline $\begin{array}{l}\text { The } \\
\text { Characteristics } \\
\text { of the skilled } \\
\text { person }\end{array}$ & $\begin{array}{l}\text { Pre } \\
\text { Counseling }\end{array}$ & $\begin{array}{l}\text { Counseling } \\
\text { I }\end{array}$ & $\begin{array}{l}\text { Counseling } \\
\text { II }\end{array}$ \\
\hline $\begin{array}{l}\text { Responsiveness } \\
\text { Realism }\end{array}$ & Fair & High & High \\
$\begin{array}{l}\text { Relating } \\
\text { Rewarding }\end{array}$ & Fair & Fair & High \\
activity & Poor & Fair & Fair \\
Right \& Wrong & Poor & Poor & Fair \\
\hline
\end{tabular}

Name: YR

\begin{tabular}{llll}
$\begin{array}{l}\text { The } \\
\text { Characteristics } \\
\text { of the skilled } \\
\text { person }\end{array}$ & $\begin{array}{l}\text { Pre } \\
\text { Counseling }\end{array}$ & $\begin{array}{l}\text { Counseling } \\
\text { I }\end{array}$ & $\begin{array}{l}\text { Counseling } \\
\text { II }\end{array}$ \\
\hline $\begin{array}{l}\text { Responsiveness } \\
\text { Realism }\end{array}$ & Fair & High & High \\
$\begin{array}{l}\text { Relating } \\
\text { Rewarding }\end{array}$ & Poor & Fair & High \\
activity & Poor & Fair & Fair \\
Right \& Wrong & Poor & Poor & Fair \\
\hline
\end{tabular}

Name: AS

\begin{tabular}{llll}
\hline $\begin{array}{l}\text { The } \\
\text { Characteristics } \\
\text { of the skilled } \\
\text { person }\end{array}$ & $\begin{array}{l}\text { Pre } \\
\text { Counseling }\end{array}$ & $\begin{array}{l}\text { Counseling } \\
\text { I }\end{array}$ & $\begin{array}{l}\text { Counseling } \\
\text { II }\end{array}$ \\
\hline $\begin{array}{l}\text { Responsiveness } \\
\text { Realism }\end{array}$ & Fair & High & High \\
$\begin{array}{l}\text { Relating } \\
\text { Rewarding }\end{array}$ & Poor & Fair & High \\
activity & Poor & Fair & Fair \\
Right \& Wrong & Poor & Poor & Fair \\
\hline
\end{tabular}

Name: RW

\begin{tabular}{|c|c|c|c|}
\hline $\begin{array}{l}\text { The } \\
\text { Characteristics } \\
\text { of the skilled } \\
\text { person }\end{array}$ & $\begin{array}{l}\text { Pre } \\
\text { Counseling }\end{array}$ & $\begin{array}{l}\text { Counseling } \\
\text { I }\end{array}$ & $\begin{array}{l}\text { Counseling } \\
\text { II }\end{array}$ \\
\hline Responsiveness & Fair & Fair & Fair \\
\hline Realism & Poor & Poor & Fair \\
\hline Relating & Poor & Poor & Fair \\
\hline $\begin{array}{l}\text { Rewarding } \\
\text { activity }\end{array}$ & Poor & Poor & Fair \\
\hline Right \& Wrong & Poor & Poor & Poor \\
\hline
\end{tabular}

\section{Information:}

High: The criteria for students having all aspects in Responsiveness, Realism, Relating, Rewarding activity, Right \& Wrong.

Fair: There are several aspects $(25 \%)$ that students do not have.

Poor: The criteria for students are only (50\%) of the aspects in Responsiveness, Realism, Relating, Rewarding activity, Right \& Wrong.

\section{The Strengths and The Weaknesses of Religious-Based Responsive Services in improving Student Life Skills}

This religious-based responsive service uses religious-based life skills counseling and consultation, the strength of the implementation of religious-based life skills counseling and consultation

In the implementation of religious-based life skill counseling group members selection is simpler because researchers as academic advisers to clients / counselees often communicate. So that, it is easy to find students who have Responsiveness, namely skills associated with awareness of their existence, understanding their feelings, understanding their internal motivation, and agreement, and sensitivity to anxiety and guilt; Realism, which is the ability to think realistically; Relating, namely skills in initiating, listening, giving care, cooperating, asserting and managing anger and conflict; Rewarding activity, which includes identifying skills, interesting in working skills, study skills (learning), skills in utilizing leisure time, and skills in maintaining physical health; Right \& Wrong, which is related to the skill of applying ethics in social life, still needs to be improved. The function of researchers as counselors and observers strongly supports the achievement of research objectives. In carrying out the stages in counseling, the religious-based life skill counseling is also easier. The function of strengthening group members in achieving specific goals is quite smooth. The verses of the Qur'an which are relevant to improve the life skill of the counselee are precisely and easily digested by the client. One of the hallmarks of religious-based life skills counseling compared to individual oriented behavioral counseling is the atmosphere of a living group and mutual input in solving problems

\section{1) The weaknesses in the implementation of religious-based life skills counseling}

Some things that become weaknesses in the implementation of life skills counseling include timeliness in counseling. Counselors / clients with different behavioral targets need complete different facilities and media. So that, they need a lot of mind power. The counselees take a long time to learn and to digest the meanings of the Qur'an verses

\section{DISCUSSION}

In this discussion, the following are the implementation of religious-based life skills counseling:

\section{A. The First Religious Based Life Skills Counseling}

Group counseling is conducted in November 2018, at the BK-Counseling Guidance laboratory. The group is formed by its members consisting of five students who have Responsiveness, namely skills related to awareness of their existence, understanding their feelings, understanding their internal motivation, and agreement, and sensitivity to anxiety and guilt. Realism, which is the ability to think realistically. Relating, 
namely skills in initiative, listening, giving care, cooperating, asserting and managing anger and conflict. Rewarding activity, which includes identifying skills, interest in work skills, study skills (learning), skills to use leisure time, and skills in maintaining physical health. Right $\boldsymbol{\&}$ Wrong, which is related to the skill of applying ethics in social life. There are still need to be improved, namely DD, IS, YR, US, and RW. The researcher conducted religious-based life skills counseling through five stages. First are developing relationships, identifying and clarifying problems. Second are assessing the problem and re-identifying the main problem of the client. Third are formulating goals and planning interventions. Fourth is providing interventions to develop client skills to help themselves (Self Helping). Fifth are ending counseling and consolidating. The results of the first religious-based life skills counseling activities are within one month after the counseling. AS and RW counselees are still not showing the behaviors covered in the characteristics of the skilled person namely Responsiveness, Realism, Relating, Rewarding activity, and Right \& Wrong.

On the other hand, the DD and IS counselees have shown progress, their behavior for Responsiveness, Realism, Relating, Rewarding activity, Right \& Wrong have increased. This can be achieved because they are diligent in consulting related to the problems at hand. However, the behavior covered by Right \& Wrong still needs to be improved. YR counselee has a slight increase in behavior in Relating, Rewarding activity, Right \& Wrong. He is less active in consulting and less motivated to achieve success. If there are problems, He complains more and blame others. This first life skills counseling is conducted one week in a row, meaning four times in November 2018

\section{B. The Second Counseling Application of Religious Based Life Skills}

The second religious-based life skills counseling was conducted in December 2018. Researchers conducted counseling with more emphasis on the Fourth stage, namely Providing interventions to develop client skills to help themselves (Self Helping). Next, the fifth stage is to end counseling and consolidate. This is done so that the counselee more concentrates on achieving the goal of counseling. DD and IS counselees have been able to achieve an increase their Life Skills well,. YR and AS Counselors achieve their life skills sufficiently. RW Counselors are not able to achieve Life Skills well, since they still very often show behavior in their Right \& Wrong inability. This happens because of the influence of the environment, personality, and motivation to HIgh of each counselee. The frequency of consultation also plays a role for changes in counselee behavior. That means there are life skill changes caused by the counselor's warm attitude in conducting consultations. The condition of the counselee's thoughts and feelings are ready to make changes, however, from the five counselees there is still one counselee who has not maximized his life skill improvement. The second life skills counseling is conducted once a week to become four times in
December 2018.

\section{CONCLUSION}

Life skills of FKIP-Educational Faculty Of Education Science of UNISRI-Slamet Riyadi University students are very varied, most of them have high life skills, but there is a group of students who do not have a good life skill. There are five students identified still had to be helped to have a high life skill.

The implementation of religious-based responsive services with religious-based life skills counseling techniques is very interesting for students. So, it is effective to improve student life skills. This is indicated by the change in counselee behavior that has done religious-based skills counseling for eight times in two months..

The implementation of counseling on religious-based life skills has the advantage of the function of researchers as counselors and observers which is very supportive in achieving research objectives. In carrying out the stages in counseling, the religious life-based life skill is also easier. The function of strengthening group members achieving specific goals is quite smooth. The verses of the Qur'an are relevant to improve the life skill of the counselee. They are precisely and easily digested by the client. While the disadvantage is that religious-based life skills counseling requires a long time because counselees / clients have different behavioral goals. The counselee takes a long time in learning and digesting the meanings in the verses of the Qur'an.

\section{SUGGESTION}

Based on the above conclusions, things can be suggested as follows:

1. Higher education institutions should facilitate the environment and academic environment to support student life skills.

2. The lecturer should help students improve the life skills of students using services in varied counseling oriented towards achieving goals.

3. Students and lecturers should complete the shortcomings in implementing religious-based responsive services through religious-based life skills counseling techniques as a mean to improve student life skills.

\section{REFERENCES}

[1] Corey. Theory and practice of group counseling (3, ed.). Pasific Grove, California: Brooks/Colr Publishing Company.1990.

[2] Emzir. Metodologi Penelitian Kualitatif ANALISIS DATA, Jakarta: Raja Grafindo Persada. 2010.

[3] Gantina, dkk. Asesmen Teknik Nontes dalam Perspektif BK Komprehensif, Jakarta: Indeks. 2011

[4] H.B. Sutopo. Metodologi Penelitian Kualitatif, Dasar Teori dan Terapannya dalam Penelitian, Surakarta: Universitas Sebelas Maret.2006. 
[5] Yanti Hera, International Journal of Education Dewantara" The Problem-Based Entrepreneurship Learning Model Development to Improve The Life Skills of Teacher Training Students in Private Universities throughout Solo Raya. ISSN: 2302-2620, Number 1, Volume

Web:Jurnal.fkip.uns.ac.id/index.php/dewantara/artikel/view/2242/1630

[6] Yanti Hera, Online Internasional Interdiciplinery research Journal Model Development of Teenage Group Counseling Based on Comprehensive Intelligence to Increase Student Character (Research and Education Faculty in Solo Area, 214/215 Academic Year). Web: www.oiirj.org/oiirj/jan 2016-special-issue/04.pdf

[7] Yanti hera, Online International Educational E-Journal. The effectiveness of emotional intelligence based group counseling to enhance students responsibility" ISSN: Vol-V, Issue-IV, Oct-Nov-Dec 2016

[8] Lexy J. Moleong. Metodolgi Penelitian Kualitatif, Bandung: Remaja Rosdakarya.2002.

[9] Matthew B. Miles; A. Michael Huberman. Analisis data Kualitatif. Jakarta: Universitas Indonesia.1992.

[10] Nasution. Metode Research, Jakarta: Bumi Aksara.2002.

[11] Prayito dan Erman Anti. Dasar-Dasar bimbingan Konseling, Jakarta: Rineka Cipta.1999.

[12] Syamsu Yusuf; Juntik Nurihsan. Landasan Bimbingan \& Konseling, Bandung: Remaja Rosda Karya.2012

[13] Rahmad Hidayat Dede, Aip Badrujaman,. Penelitian Tindakan Dalam Bimbingan Konseling, Jakarta: Indeks, 2012.

[14] Sugiyono. Metode penelitian Kuantitatif, Kualitatif, Dan R\&D. Bandung: Alfabeta.2010.

[15] Suharsimi Arikunto. Prosedur Penelitian Suatu Pendekatan Praktek, Jakarta: Rineka Cipta.2002. 